Article

\title{
Cytotoxic Polyketides from the Marine Sponge-Derived Fungus Pestalotiopsis heterocornis XWS03F09
}

\author{
Hui Lei ${ }^{1,+}{ }^{\oplus}$, Jing Lei ${ }^{1,+}{ }^{,}$Xuefeng Zhou ${ }^{2}{ }^{\oplus}$, Mei Hu ${ }^{1}$, Hong Niu ${ }^{1}$, Can Song ${ }^{1}$, Siwei Chen ${ }^{1}$, \\ Yonghong Liu $^{2, *}$ and Dan Zhang ${ }^{1, *}$ \\ 1 School of Pharmacy, Southwest Medical University, Luzhou, Sichuan 646000, China \\ 2 CAS Key Laboratory of Tropical Marine Bio-resources and Ecology/Guangdong Key Laboratory of Marine \\ Materia Medica, South China Sea Institute of Oceanology, Chinese Academy of Sciences, \\ Guangzhou 510301, China \\ * Correspondence: yonghongliu@scsio.ac.cn (Y.L.); zhangdan@swmu.edu.cn (D.Z.) \\ + These authors contributed equally to this work.
}

Received: 26 June 2019; Accepted: 17 July 2019; Published: 22 July 2019

check for updates

\begin{abstract}
Four new compounds, including two new polyketides, heterocornols $M$ and $N(\mathbf{1}, \mathbf{2})$, and a pair of epimers, heterocornols $\mathrm{O}$ and $\mathrm{P}(3,4)$, were isolated from the fermentation broth of the marine sponge-derived fungus Pestalotiopsis heterocornis XWS03F09, together with three known compounds (5-7). The new chemical structures were established on the basis of a spectroscopic analysis, optical rotation, experimental and calculated electronic circular dichroism (ECD). All of the compounds (1-7) were evaluated for their cytotoxic activities, and heterocornols M-P (1-4) exhibited cytotoxicities against four human cancer cell lines with $\mathrm{IC}_{50}$ values of 20.4-94.2 $\mu \mathrm{M}$.
\end{abstract}

Keywords: marine-derived fungus; cytotoxicity; polyketide

\section{Introduction}

Marine-derived microorganisms have been attracting widespread attention as a huge resource for the discovery of bioactive natural products [1]. The genus Pestalotiopsis, widely distributed throughout the world, is known to produce a wide range of structurally diverse secondary metabolites with various bioactivities including polyketides [2-5], terpenoids [6-8], alkaloids [9,10] and others, with diverse bioactivities including antitumor, antibacterial, acetylcholinesterase inhibitory, antioxidant and anti-HIV.

Recently, we reported sixteen new compounds including heterocornols A-L [11], pestaloisocoumarins $\mathrm{A}$ and $\mathrm{B}$, isopolisin $\mathrm{B}$, and pestalotiol A [12], from the fungus Pestalotiopsis heterocornis (XWS03F09), which have been shown to exhibit cytotoxic and antibacterial activities in vitro. In order to obtain more new bioactive natural products from species of this genus, a strain of Pestalotiopsis heterocornis was refermented in the same culture medium. The chemical investigation of this fungus led to the isolation and identification of four new polyketide derivatives, heterocornols M-P (1-4), together with three known compounds, $(R)-3-H y d r o x y-1-[(R)-4$-hydroxy-1,3-dihydroisobenzofuran-1-yl]butan-2-one (5) [13], (R)-3-Hydroxy-1-[(S)-4-hydroxy-1,3-dihydroisobenzofuran-1-yl]butan-2-one (6) [13], 4,8-dihydroxy-1-tetralone (7) [14] (Figure 1). The structures of the new compounds, including absolute configurations, were elucidated on the basis of spectroscopic data and a CD Cotton effects analysis. The details of the isolation, structures elucidation, and cytotoxic activity against the human cancer cell lines of these compounds are reported herein. 
<smiles>CC(C)=CCc1ccc(O)c2c1[C@@H](CCO)OC2</smiles>

1<smiles>C[C@H](O)C(=O)C[C@H]1OCc2c(O)cccc21</smiles>

5<smiles>C[13CH](O)[C@]1([14CH](C)O)C=Cc2cccc(O)c2CO1</smiles>

2<smiles>C[C@H](O)C(=O)C[C@H]1OCc2c(O)cccc21</smiles>

6<smiles>CC(O)[C@@H]1C=Cc2cccc3c2C(CC(C)(O)O3)O1</smiles>

3<smiles>O=C1CC[C@H](O)c2cccc(O)c21</smiles>

7

Figure 1. Structures of compounds 1-7.

\section{Results and Discussion}

\subsection{Structure Elucidation of the Compounds}

Compound 1 was obtained as white amorphous powder and possessed a molecular formula of $\mathrm{C}_{15} \mathrm{H}_{20} \mathrm{O}_{3}$ as defined by the ${ }^{13} \mathrm{C}-\mathrm{NMR}$ and HRESIMS data (Figure S1). The ${ }^{1} \mathrm{H}-\mathrm{NMR}$ spectrum (Table 1 ) (Figure S2) data displayed notable signals including two methyls $\left(\delta_{\mathrm{H}} 1.73, \mathrm{~s} ; \delta_{\mathrm{H}} 1.71\right.$, s), two oxygenated methylenes $\left(\delta_{\mathrm{H}} 5.02, \mathrm{dd}, J=12.1,2.3 \mathrm{~Hz}, \delta_{\mathrm{H}} 4.95, \mathrm{~d}, J=12.1 \mathrm{~Hz} ; \delta_{\mathrm{H}} 3.73, \mathrm{~m}, \delta_{\mathrm{H}} 3.66\right.$, ddd, $J=11.0,7.7$, $4.7 \mathrm{~Hz})$, two methylenes $\left(\delta_{\mathrm{H}} 3.18, \mathrm{dd}, J=15.7,7.0 \mathrm{~Hz}, \delta_{\mathrm{H}} 3.25, \mathrm{dd}, J=15.7,7.1 \mathrm{~Hz} ; \delta_{\mathrm{H}} 1.78, \mathrm{~m}, \delta_{\mathrm{H}}\right.$ 2.04 , ddd, $J=14.8,7.7,2.4 \mathrm{~Hz})$, and an oxygenated methine $\left(\delta_{\mathrm{H}} 5.39, \mathrm{~m}\right)$. In addition, two aromatic protons at $\delta_{\mathrm{H}} 6.60(\mathrm{~d}, J=8.0 \mathrm{~Hz})$ and $\delta_{\mathrm{H}} 6.87(\mathrm{~d}, J=8.0 \mathrm{~Hz})$ were observed. The general features of its NMR spectroscopic data closely resembled those of heterocornol I [11]. The major difference was the absence of two oxygenated methine bonds, and the presence of an oxygenated methylene $\left(\delta_{\mathrm{H}} 3.73\right.$, $\left.\mathrm{m}, \delta_{\mathrm{H}} 3.66, \mathrm{ddd}, J=11.0,7.7,4.7 \mathrm{~Hz}\right)$ in 1. Furthermore, HMBC correlations from $\mathrm{H}-9\left(\delta_{\mathrm{H}} 2.04\right.$ and $1.78)$ to $C-8\left(\delta_{C} 82.7\right)$ and $C-7\left(\delta_{C} 142.6\right)$, from $\mathrm{H}-10\left(\delta_{\mathrm{H}} 3.73\right.$ and 3.66$)$ to $C-9\left(\delta_{C} 38.9\right)$ and C-8 $\left(\delta_{C} 82.7\right)$, and from H-11 $\left(\delta_{\mathrm{H}} 3.25\right.$ and 3.18) to C-12 $\left(\delta_{C} 124.1\right), \mathrm{C}-5\left(\delta_{\mathrm{C}} 130.4\right), \mathrm{C}-6\left(\delta_{\mathrm{C}} 127.0\right)$, and C-7 $\left(\delta_{\mathrm{C}} 142.6\right)$ confirmed the planar structure of $\mathbf{1}$, as shown in Figure 1. The relative configuration of $\mathbf{1}$ was deduced by comparing with previous reports on related fungal metabolites [11,13]. A negative Cotton effect at $207 \mathrm{~nm}$ (Figure 2) was observed in the CD spectrum of 1, suggesting an $8 R$ configuration. Thus, compound 1 was determined, and named heterocornol $\mathrm{M}$.

Compound 2 was isolated as a white amorphous solid. Its molecular formula was determined as $\mathrm{C}_{14} \mathrm{H}_{18} \mathrm{O}_{4}$ on the basis of HRESIMS at $m / z 273.1120[\mathrm{M}+\mathrm{Na}]^{+}$(calcd 273.1103). A comparison of the ${ }^{1} \mathrm{H}$ and ${ }^{13} \mathrm{C}-\mathrm{NMR}$ data with those of heterocornol $\mathrm{C}$ [11] revealed a high degree of similarity. The major difference was due to the presence of signals of $-\mathrm{CH}_{2} \mathrm{OHCH}_{3}$ moiety in 2. Compared to heterocornol $C$, compound 2 showed an additional oxygenated quaternary carbon $\left(\delta_{C} 103.8\right)$ atom signal instead of the methine signal. The HMBC correlations from $\mathrm{H}-11\left(\delta_{\mathrm{H}} 3.94\right)$ to $\mathrm{C}-12\left(\delta_{\mathrm{C}} 14.3\right)$ and $\mathrm{C}-10\left(\delta_{\mathrm{C}} 103.8\right)$ and from $\mathrm{H}-13\left(\delta_{\mathrm{H}} 3.90\right)$ to $\mathrm{C}-14\left(\delta_{\mathrm{C}} 14.8\right), \mathrm{C}-10\left(\delta_{\mathrm{C}} 103.8\right)$, and $\mathrm{C}-9\left(\delta_{\mathrm{C}} 130.1\right)$ revealed that the $-\mathrm{CH}_{2} \mathrm{OHCH}_{3}$ moiety was located at $\mathrm{C}-10\left(\delta_{\mathrm{C}} 103.8\right)$ in 2.

According to the literature $[15,16]$, the absolute configuration of typical pestalospirane B was determined using NOE, a total synthesis, and an X-ray crystallographic analysis. The similar CD spectral data between compound 2 and pestalospirane B indicated that 2 (C-11 and C-13) possessed the same relative configuration as pestalospirane $\mathrm{B}\left(\mathrm{C}-12, \mathrm{C}-12^{\prime}\right)$. In addition, considering the possible biosynthesis of 2 , we suggest that $\mathrm{C}-11$ and $\mathrm{C}-13$ are also in the $S$-configuration. Moreover, the NOESY spectrum revealed the relative configuration of $\mathbf{2}$, as shown in Figure 3. Based on the above discussion, 
the absolute configuration of 2 was concluded to be 11S,13S, in that the calculated ECD curve of $(11 S, 13 S)-\mathbf{2}$ had a good agreement with the experimental data (Figure 4). Thus, the structure of 2 was assigned, and named heterocornol $\mathrm{N}$.

Table 1. ${ }^{1} \mathrm{H}(500 \mathrm{MHz})$ and ${ }^{13} \mathrm{C}-\mathrm{NMR}(125 \mathrm{MHz})$ data for compounds 1 and 2 in $\mathrm{CD}_{3} \mathrm{OD}$.

\begin{tabular}{|c|c|c|c|c|}
\hline \multirow{2}{*}{ Position } & \multicolumn{2}{|r|}{1} & \multicolumn{2}{|c|}{2} \\
\hline & $\delta_{C}$, Type & $\delta_{\mathrm{H}}(J$ in $\mathrm{Hz})$ & $\delta_{C}$, Type & $\delta_{\mathrm{H}}(J$ in $\mathrm{Hz})$ \\
\hline 1 & $71.4, \mathrm{CH}_{2}$ & $\begin{array}{c}5.02, \mathrm{dd}(12.1,2.3) \\
4.95, \mathrm{~d}(12.1)\end{array}$ & $56.4, \mathrm{CH}_{2}$ & $\begin{array}{l}4.99, \mathrm{~d}(13.7) \\
4.45, \mathrm{~d}(13.7)\end{array}$ \\
\hline 2 & $125.9, \mathrm{C}$ & & $126.1, \mathrm{C}$ & \\
\hline 3 & $150.9, \mathrm{C}$ & & 153.6, C & \\
\hline 4 & $115.3, \mathrm{CH}$ & $6.60, \mathrm{~d}(8.0)$ & 114.1, CH & $6.65, \mathrm{~d}(7.8)$ \\
\hline 5 & $130.4, \mathrm{CH}$ & $6.87, \mathrm{~d}(8.0)$ & 127.7, $\mathrm{CH}$ & $7.43, \mathrm{~d}(7.8)$ \\
\hline 6 & 127.0, C & & 121.6, CH & $6.74, \mathrm{~d}(7.8)$ \\
\hline 7 & 142.6, C & & 136.7, C & \\
\hline 8 & $82.7, \mathrm{CH}$ & $5.39, \mathrm{~m}$ & 131.1, CH & $6.60, \mathrm{~d}(12.5)$ \\
\hline 9 & $38.9, \mathrm{CH}_{2}$ & $\begin{array}{c}2.04, \text { ddd }(14.8,7.7,2.4) 9 \\
1.78, \mathrm{~m}\end{array}$ & $130.1, \mathrm{CH}$ & $5.93, \mathrm{~d}(12.5)$ \\
\hline 10 & $60.1, \mathrm{CH}_{2}$ & $\begin{array}{c}3.73, \mathrm{~m} ;(7.7) \\
3.66, \operatorname{ddd}(11.0,7.7,4.7)\end{array}$ & 103.8, C & \\
\hline 11 & $31.5, \mathrm{CH}_{2}$ & $\begin{array}{l}\text { 3.25, dd }(15.7,7.1) \\
3.18, \mathrm{dd}(15.7,7.0)\end{array}$ & $69.3, \mathrm{CH}$ & $3.94, q(6.5)$ \\
\hline 12 & 124.1, CH & $5.21, \mathrm{t}(7.0)$ & $14.3, \mathrm{CH}_{3}$ & $1.24, \mathrm{~d}(6.5)$ \\
\hline 13 & 133.3, C & & $67.1, \mathrm{CH}$ & $3.90, q(6.5)$ \\
\hline 14 & $25.8, \mathrm{CH}_{3}$ & $1.73, \mathrm{~s}$ & $14.8, \mathrm{CH}_{3}$ & $0.98, \mathrm{~d}(6.5)$ \\
\hline 15 & $18.0, \mathrm{CH}_{3}$ & $1.71, \mathrm{~s}$ & & \\
\hline
\end{tabular}

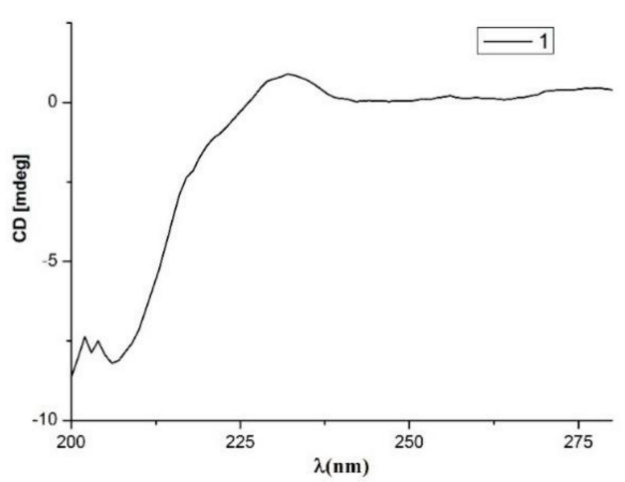

Figure 2. The circular dichroism (CD) spectra of 1.

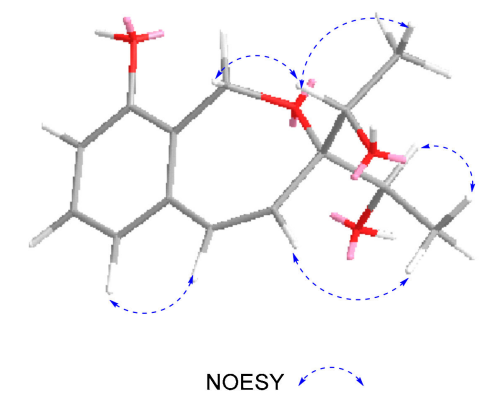

Figure 3. NOESY correlations of 2. 


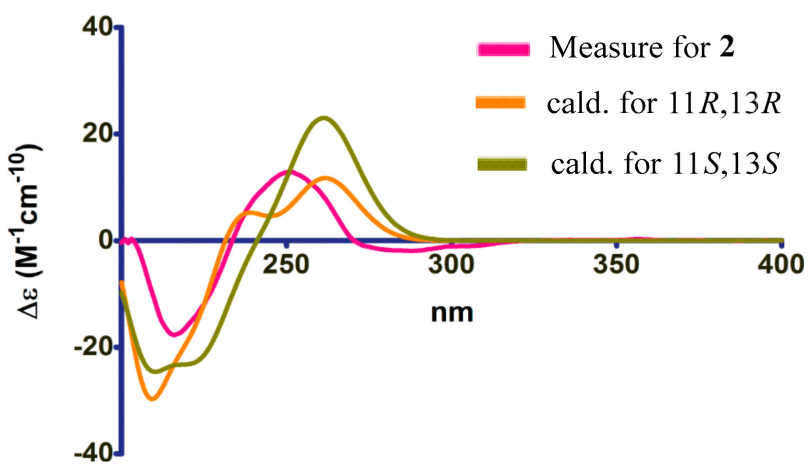

Figure 4. The ECD spectra of 2.

The same molecular formula of $\mathrm{C}_{15} \mathrm{H}_{18} \mathrm{O}_{4}$, as established by HRESIMS and their very similar NMR data (Table 2), suggested that compounds 3 and 4 are a pair of epimers in a nearly 1:1 ratio. The separation of compounds 3 and $\mathbf{4}$ by several chromatographic methods was unsuccessful. Fortunately, the NMR data for 3 and 4 were similar to those of $\mathbf{2}$, with the exception of an additional six-membered ring with a hemiacetal group. In addition, the chemical shifts of $C-15\left(\delta_{C} 39.4 / 37.7\right), C-14\left(\delta_{C} 97.4 / 95.9\right)$, and $C-13\left(\delta_{C} 26.1 / 26.6\right)$ were observed. These data indicated that 3 and 4 were two hemiacetal derivatives of 2 , which was further supported by the HMBC correlations of $\mathrm{H}-15\left(\delta_{\mathrm{H}} 2.32 / 2.42\right)$ to $\mathrm{C}-1$ $\left(\delta_{C} 65.8 / 65.3\right), C-14\left(\delta_{C} 97.4 / 95.9\right)$, and C-2 $\left(\delta_{C} 123.3 / 120.7\right)$, and H-13 $\left(\delta_{H} 1.57 / 1.60\right)$ to C-15 $\left(\delta_{C} 39.4 / 37.7\right)$ and C-14 $\left(\delta_{C} 97.4 / 95.9\right)$ (Figure 5). Due to the lack of material, the configurations of C-11 and C-15 in 3 and 4 could not be determined from single crystals and the modified Mosher's method. Thus, the structures of 3 and 4 were assigned, and named heterocornol $\mathrm{O}(3)$ and heterocornol $\mathrm{P}(4)$.

The known compounds 5-7 were identified as $(R)-3-$ Hydroxy-1-[(R)-4-hydroxy-1,3dihydroisobenzofuran-1-yl]butan-2-one (5) [13], (R)-3-Hydroxy-1-[(S)-4-hydroxy-1,3dihydroisobenzofuran-1-yl]butan-2-one (6) [13], and 4,8-dihydroxy-1-tetralone (7) [14] by a comparison of the ${ }^{1} \mathrm{H}$ and ${ }^{13} \mathrm{C}-\mathrm{NMR}$, and of the MS spectroscopic data with those reported.

Table 2. The ${ }^{1} \mathrm{H}(500 \mathrm{MHz})$ and ${ }^{13} \mathrm{C}-\mathrm{NMR}(125 \mathrm{MHz})$ data for compounds 3 and 4.

\begin{tabular}{|c|c|c|c|c|}
\hline \multirow{2}{*}{ Position } & \multicolumn{2}{|c|}{$3\left(\right.$ in $\left.C_{3} \mathrm{OD}\right)$} & \multicolumn{2}{|c|}{$4\left(\right.$ in $\left.\mathrm{CD}_{3} \mathrm{OD}\right)$} \\
\hline & $\delta_{C}$, Type & $\delta_{H}(J$ in $\mathrm{Hz})$ & $\delta_{C}$, Type & $\delta_{H}(J$ in $\mathbf{H z})$ \\
\hline 1 & $65.8, \mathrm{CH}$ & $4.80, \mathrm{t}(7.3)$ & $65.3, \mathrm{CH}$ & $4.60, \mathrm{dd}(5.7,2.3)$ \\
\hline 2 & $123.3, \mathrm{C}$ & & $120.7, C$ & \\
\hline 3 & $152.2, \mathrm{C}$ & & $151.8, \mathrm{C}$ & \\
\hline 4 & $115.5, \mathrm{CH}$ & 6.69, brd $(8.1)$ & 116.0, $\mathrm{CH}$ & 6.78, brd $(7.7)$ \\
\hline 5 & $128.2, \mathrm{CH}$ & $7.16, \mathrm{t}(8.1)$ & $128.9, \mathrm{CH}$ & $7.26, \mathrm{t}(7.9)$ \\
\hline 6 & 122.1, CH & 6.85, brd (7.9) & $120.4, \mathrm{CH}$ & 6.89, brd (7.7) \\
\hline 7 & $137.4, \mathrm{C}$ & & $138.9, \mathrm{C}$ & \\
\hline 8 & $130.0, \mathrm{CH}$ & $6.67, \mathrm{dd}(12.0,1.7)$ & $132.6, \mathrm{CH}$ & $6.90, \mathrm{dd}(11.3,2.0)$ \\
\hline 9 & $131.3, \mathrm{CH}$ & $6.28, \mathrm{dd}(12.0,3.4)$ & $129.6, \mathrm{CH}$ & $6.27, \mathrm{dd}(11.3,4.7)$ \\
\hline 10 & $81.7, \mathrm{CH}$ & $3.93, \mathrm{~m}$ & $78.6, \mathrm{CH}$ & $3.81, \mathrm{~m}$ \\
\hline 11 & $69.0, \mathrm{CH}$ & $3.94, \mathrm{~m}$ & $68.6, \mathrm{CH}$ & 3.91 , quint (6.4) \\
\hline 12 & $19.2, \mathrm{CH}_{3}$ & $1.27, \mathrm{~d}(6.0)$ & $18.3, \mathrm{CH}_{3}$ & $1.21, \mathrm{~d}(6.4)$ \\
\hline 13 & $26.1, \mathrm{CH}_{3}$ & $1.57, \mathrm{~s}$ & $26.6, \mathrm{CH}_{3}$ & $1.60, \mathrm{~s}$ \\
\hline 14 & $97.4, \mathrm{C}$ & 2.32, dd $(13.6,7.0)$ & $95.9, \mathrm{C}$ & $2.42, \mathrm{dd}(14.7,2.3)$ \\
\hline 15 & $39.4, \mathrm{CH}_{2}$ & 2.10, dd $(13.6,7.5)$ & $37.7, \mathrm{CH}_{2}$ & 2.17 , dd $(14.7,5.7)$ \\
\hline
\end{tabular}




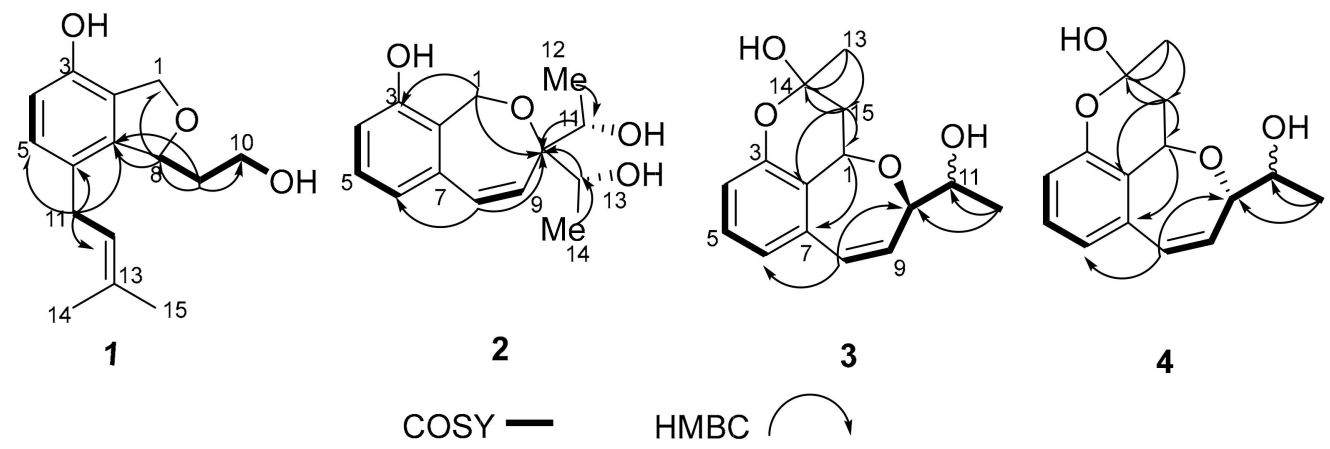

Figure 5. ${ }^{1} \mathrm{H}-{ }^{1} \mathrm{H}$ COSY and $\mathrm{HMBC}$ correlations of $\mathbf{3} / \mathbf{4}$.

\subsection{Biological Activities}

All of the compounds were evaluated for their cytotoxic activities against four human cancer cell lines (Table 3). Heterocornols M-P (1-4) exhibited cytotoxicities against four human cancer cell lines with $\mathrm{IC}_{50}$ values of 20.4-94.2 $\mu \mathrm{M}$. Compound 2 showed no cytotoxicity against the four human cancer cell lines when tested at $100 \mu \mathrm{M}$.

Table 3. Cytotoxic activities of compounds $1-7$ ( $\mathrm{IC}_{50}$ in $\left.\mu \mathrm{M}\right)$.

\begin{tabular}{ccccc}
\hline Compound & BGC-823 & Ichikawa & HepG2 & $\mathbf{7 8 6 0}$ \\
\hline 1 & 61.1 & $>100$ & 20.4 & $>100$ \\
2 & $>100$ & $>100$ & $>100$ & $>100$ \\
$3 / 4$ & 35.0 & 54.3 & 42.0 & 22.1 \\
5 & 82.1 & 65.3 & 94.2 & $>100$ \\
6 & 78.1 & 58.5 & 85.4 & $>100$ \\
7 & $>100$ & $>100$ & $>100$ & $>100$ \\
Adriamycin & 1.3 & 1.2 & 1.5 & 2.0 \\
\hline
\end{tabular}

\section{Materials and Methods}

\subsection{General Experimental Procedures}

Optical rotations were measured with an AntonPaar MCP 200 automatic polarimeter. Ultraviolet (UV) spectra were obtained on a UV-2550 spectrophotometer (Shimadzu Corporation, Tokyo, Japan). IR spectra were recorded on a Bruker Tensor 27 FT-IR spectrometer (film). 1D and 2D-NMR spectra were carried out on a Bruker AM-400 and an Avance-500 spectrometer, $\delta$ in ppm rel. to TMS, $J$ in Hz. ESIMS and HRESIMS were measured with a Bruker miXis TOF-QII mass spectrometer (Bruker, Fällanden, Switzerland), respectively. Silica gel (100-200 mesh, 300-400 mesh, Qingdao Marine Chemical Ltd., Qingdao, China), Sephadex LH-20 (GE Healthcare Bio-sciences AB, Uppsala, Sweden), and YMC GEL ODS-A (S-50 $\mu \mathrm{m}, 12 \mathrm{~nm}$ ) (YMC Co., Ltd., Kyoto, Japan) were used for column chromatography. Semipreparative HPLC analyses were performed using an ODS column (YMC-ODS-A, $250 \times 20 \mathrm{~mm}$, $5 \mu \mathrm{m}$ ). Circular dichroism (CD) spectra were measured on a Chirascan circular dichroism spectrometer (Applied Photophysics Ltd., Leatherhead, UK). MTT assays were analyzed using a microplate reader (BioTek Synergy H1, BioTek Instruments, Inc., Vermont, USA).

\subsection{Fungal Material}

The culture of Pestalotiopsis sp. XWS03F09 was isolated from the sponge Phakellia fusca, which was collected from the Xisha Islands of China. The strain was identified as Pestalotiopsis heterocornis by Xiuping Lin based on DNA amplification and an ITS region sequence analysis. The result showed that the sequence was most similar (100\%) to the sequence of P. heterocornis (GenBank database). The strain (No. XWS03F09) was deposited in the School of Pharmacy, Southwest Medical University, Luzhou, Sichuan, China. 


\subsection{Fermentation, Extraction, and Isolation}

The strain Pestalotiopsis heterocornis XWS03F09 was inoculated into $1000 \mathrm{~mL}$ conical flasks containing a seed medium composed of rice at $200 \mathrm{~g} / \mathrm{L}$ of, artificial sea salt at $5 \mathrm{~g} / \mathrm{L}$, and distilled water at $200 \mathrm{~mL} / \mathrm{L}$. The mass fermentation of this fungus was cultivated statically for 60 days. The solid cultures were extracted with EtOAc four times at room temperature, after which the EtOAc solutions were evaporated under reduced pressure to afford $52.2 \mathrm{~g}$ of crude extract.

The crude extract was subjected to silica gel column chromatography (CC) (PE-EtOAc (50:1 to 0:1, $v / v$ ) to yield 7 fractions (Frs.1-7). Fraction 4 was fractionated with repeated CC on a silica gel column eluting with a gradient of PE-EtOAc $(8: 1$ to $0: 1, v / v)$ to produce three subfractions (Frs. 4.1-4.3). Fr. 4.1 was chromatographed on Sephadex LH-20 eluted with $\mathrm{MeOH}$ to afford three subfractions (Frs. 4.1.1-4.1.3). Fr. 4.1.2 was further separated by preparative HPLC with $\mathrm{MeOH}-\mathrm{H}_{2} \mathrm{O}(75: 25, v / v)$ to yield 1 (10.0 mg). Fr. 4.1.3 was further separated by ODS CC, eluting with MeOH-water (80\%) to yield compounds $3 / 4(3.5 \mathrm{mg})$. Fr. 4.2 was isolated by CC on silica gel eluted with $\mathrm{CH}_{2} \mathrm{Cl}_{2}-$ Acetone (20:1 to $0: 1, v / v$ ) to afford five subfractions (Frs. 4.2.1-4.2.5). Fr. 4.2.2 was separated by ODS CC, eluting with $\mathrm{MeOH}$-water $(70: 30, v / v)$ and further purified by semipreparative HPLC $\left(65 \% \mathrm{MeOH} / \mathrm{H}_{2} \mathrm{O}\right)$ to yield 2 and 7. Fraction 5 was separated using silica gel column chromatography eluting with $\mathrm{CH}_{2} \mathrm{Cl}_{2}$-Acetone (15:1) to yield five subfractions (Frs. 5.1-5.5). Fr. 5.4 was subjected to repeated column chromatography (Sephadex LH-20) and further purified by semipreparative HPLC $\left(60 \% \mathrm{MeOH} / \mathrm{H}_{2} \mathrm{O}\right)$ to give compounds 5 (12.0 mg) and 6 (4.5 mg).

Heterocornol M (1): white amorphous powder; $[\alpha]_{D}^{25}+13.3(c 0.60, \mathrm{MeOH}) ; \mathrm{UV}(\mathrm{MeOH}) \lambda_{\max }$ $(\log \varepsilon) 232$ (4.21) nm; IR (film) $v_{\max } 3369,2921,1600,1499,1454,1375,1297,1063 \mathrm{~cm}^{-1} ;{ }^{1} \mathrm{H}$ NMR and ${ }^{13} \mathrm{C}-\mathrm{NMR}$ data, see Table 1 ; HRESIMS $m / z 271.1312[\mathrm{M}+\mathrm{Na}]^{+}$(calcd for $\mathrm{C}_{15} \mathrm{H}_{20} \mathrm{O}_{3} \mathrm{Na}, 271.1310$ ).

Heterocornol $N$ (2): white amorphous solid; $[\alpha]_{D}^{25}-36.0$ (c 0.50, MeOH); UV (MeOH) $\lambda_{\max }(\log$ ع) 257 (4.42), 305 (4.26) nm; IR (film) $v_{\max }$ 3386, 2921, 2852, 1663, 1583, 1463, 1372, 1286, $1037 \mathrm{~cm}^{-1}$; ${ }^{1} \mathrm{H}-\mathrm{NMR}$ and ${ }^{13} \mathrm{C}-\mathrm{NMR}$ data, see Table 1 ; HRESIMS m/z $273.1120[\mathrm{M}+\mathrm{Na}]^{+}$(calcd for $\mathrm{C}_{14} \mathrm{H}_{18} \mathrm{O}_{4} \mathrm{Na}_{\text {, }}$ 273.1103).

Heterocornols $\mathrm{O}$ and $\mathrm{P}(3,4)$ : white amorphous solid; $\mathrm{UV}(\mathrm{MeOH}) \lambda_{\max }(\log \varepsilon) 212$ (4.55), 251 (4.33), 303 (4.22) nm; IR (film) $v_{\max } 3359,2921,2852,1659,1632,1580,1457,1412,1377,1339,1173,1098 \mathrm{~cm}^{-1}$; ${ }^{1} \mathrm{H}$ and ${ }^{13} \mathrm{C}-\mathrm{NMR}$ data, see Table 2; HRESIMS $m / z 285.1231[\mathrm{M}+\mathrm{Na}]^{+}$(calcd for $\mathrm{C}_{15} \mathrm{H}_{18} \mathrm{O}_{4} \mathrm{Na}, 285.1103$ ).

\subsection{Calculation of ECD Spectra}

A conformational analysis was performed by Spartan's 14 using the Merk Molecular Force Field (MMFF) (Tripos, San Francisco, CA, USA) level. The low energy conformations (Boltzmann distribution $\geq 5.0 \%$ ) of the compounds were submitted to the density functional theory (DFT) optimization at the level of b3lyp/6-31g $(\mathrm{d}, \mathrm{p})$, using the cpcm solvation model with the dielectric constant representing methanol in the Gaussian 09 software. The optimized structures were further submitted to the Time-dependent density functional theory (TDDFT) calculations at b3lyp/6-31g(d,p). The ORD values were read and Boltzman averaged using the SpecDis 1.53 (Gaussian, Berlin, Germany).

\subsection{Cytotoxicity Assay}

The cytotoxic activities of compounds 1-7 were tested in human carcinoma cell lines including a human carcinoma cell line (Ichikawa), a human gastric carcinoma cell line (BGC-823), a human liver cancer cell line (HepG2), and a human kidney cancer cell line (7860) [11]. The procedure of the cytotoxic activities evaluation described was as previously reported [11]. Adriamycin was assayed as a positive control.

\section{Conclusions}

In conclusion, seven compounds, including four new compounds, namely heterocornols M-P (1-4), together with three known compounds (5-7), were isolated from the marine-derived fungus 
P. heterocornis. The structures of the isolated compounds were elucidated through the detailed analysis of spectroscopic data as well as CD Cotton effects. All of the isolated compounds (1-7) were evaluated for their cytotoxic activities. Compounds $1,3 / 4,5$, and 6 showed cytotoxicities against four human cancer cell lines with $\mathrm{IC}_{50}$ values of 20.4-94.2 $\mu \mathrm{M}$.

Supplementary Materials: The following are available online.

Author Contributions: H.L. performed the isolation and identification; H.N. fermented the fungus; Y.L. provided the fungal material. M.H. and X.Z. performed the elucidation of structures and prepared manuscript; C.S. and S.C. contributed to the evaluation of bioactivities; J.L. contributed to the extraction. D.Z. revised the manuscript.

Funding: This work was funded by the Open Project of Guangdong Key Laboratory of Marine Materia Medica (LMM2019-2), Basic Scientific Research Fund of Southwest Medical University, China (2017-ZRZD-005), and Applied Basic Research Fund of Luzhou municipal government-Southwest Medical University (2018LZXNYD-ZK13).

Conflicts of Interest: The authors declare no conflicts of interest.

\section{References}

1. $\mathrm{Xu}, \mathrm{J} . ;$ Yang, X.B.; Lin, Q. Chemistry and biology of Pestalotiopsis-derived natural products. Fungal Divers. 2014, 66, 37-68. [CrossRef]

2. Yang, X.Y.; Zhang, J.Z.; Luo, D.Q. The taxonomy, biology and chemistry of the fungal Pestalotiopsis genus. Nat. Prod. Rep. 2012, 29, 622-641. [CrossRef] [PubMed]

3. Hemphill, C.F.P.; Daletos, G.; Liu, Z.; Lin, W.H.; Proksch, P. Polyketides from the mangrove-derived fungal endophyte Pestalotiopsis clavispora. Tetrahedron Lett. 2016, 57, 2078-2083. [CrossRef]

4. Wu, G.W.; Zhou, H.C.; Zhang, P.; Wang, X.N.; Li, W.; Zhang, W.W.; Liu, X.Z.; Liu, H.W.; Keller, N.P.; An, Z.Q.; et al. Polyketide production of pestaloficiols and macrodiolide ficiolides revealed by manipulations of epigenetic regulators in an endophytic fungus. Org. Lett. 2016, 18, 1832-1835. [CrossRef] [PubMed]

5. Hwang, I.H.; Swenson, D.C.; Gloer, J.B.; Wicklow, D.T. Disseminins and spiciferone analogues: Polyketide-derived metabolites from a fungicolous isolate of Pestalotiopsis disseminate. J. Nat. Prod. 2016, 79, 523-530. [CrossRef] [PubMed]

6. Xiao, J.; Lin, L.B.; Hu, J.Y.; Jiao, F.R.; Duan, D.Z.; Zhang, Q.; Tang, H.Y.; Gao, J.M.; Wang, L.; Wang, X.L. Highly oxygenated caryophyllene-type and drimane-type sesquiterpenes from Pestalotiopsis adusta, an endophytic fungus of Sinopodophyllum hexandrum. RSC Adv. 2017, 7, 29071. [CrossRef]

7. Li, C.S.; Yang, B.J.; Turkson, J.; Cao, S.G. Anti-proliferative ambuic acid derivatives from Hawaiian endophytic fungus Pestalotiopsis sp. FT172. Phytochemistry 2017, 140, 77-82. [CrossRef] [PubMed]

8. Gao, Z.H.; Gao, R.R.; Dong, X.R.; Zou, Z.M.; Wang, Q.; Zhou, D.M.; Sun, D.A. Selective oxidation-reduction and esterification of asiatic acid by Pestalotiopsis microspora and anti-HCV activity. Phytochem. Lett. 2017, 19, 108-113. [CrossRef]

9. Jia, Y.L.; Wei, M.Y.; Chen, H.Y.; Guan, F.F.; Wang, C.Y.; Shao, C.L. (+)- and (-)-Pestaloxazine A, a pair of antiviral enantiomeric alkaloid dimers with a symmetric spiro[oxazinane-piperazinedione] skeleton from Pestalotiopsis sp. Org. Lett. 2015, 17, 4216-4219. [CrossRef] [PubMed]

10. Beattie, K.D.; Ellwood, N.; Kumar, R.; Yang, X.Z.; Healy, P.C.; Choomuenwai, V.; Quinn, R.J.; Elliott, A.G.; Huang, J.X.; Chitty, J.L.; et al. Antibacterial and antifungal screening of natural products sourced from Australian fungi and characterisation of pestalactams D-F. Phytochemistry 2016, 124, 79-85. [CrossRef] [PubMed]

11. Lei, H.; Lin, X.P.; Han, L.; Ma, J.; Dong, K.L.; Wang, X.B.; Mu, Y.; Liu, Y.H.; Huang, X.S. Polyketide derivatives from a marine-sponge-associated fungus Pestalotiopsis heterocornis. Phytochemistry 2017, 142, 51-59. [CrossRef] [PubMed]

12. Lei, H.; Lin, X.P.; Han, L.; Ma, J.; Ma, Q.J.; Zhong, J.L.; Liu, Y.H.; Sun, T.M.; Wang, J.H.; Huang, X.S. New metabolites and bioactive chlorinated benzophenone derivatives produced by a marine-derived fungus Pestalotiopsis heterocornis. Mar. Drugs 2017, 15, 69. [CrossRef] [PubMed]

13. Kesting, J.R.; Olsen, L.; Staerk, D.; Tejesvi, M.V.; Kini, K.R.; Prakash, H.S.; Jaroszewski, J.W. Production of unusual dispiro metabolites in Pestalotiopsis virgatula endophyte cultures: HPLC-SPE-NMR, electronic circular dichroism, and time-dependent density-functional computation study. J. Nat. Prod. 2011, 74, 2206-2215. [CrossRef] [PubMed] 
14. Kokubun, T.; Veitch, N.C.; Bridge, P.D.; Simmonds, M.S.J. Dihydroisocoumarins and a tetralone from Cytospora eucalypticola. Phytochemistry 2003, 62, 779-782. [CrossRef]

15. Lee, I.K.; Jang, Y.W.; Kim, Y.S.; Yu, S.H.; Lee, K.J.; Park, S.M.; Oh, B.T.; Chae, J.C.; Yun, B.S.J. Antibiot 2009, 62, 163-165. [CrossRef] [PubMed]

16. Badrinarayanan, S.; Squire, C.J.; Sperry, J.; Brimble, M.A. Bioinspired total synthesis and stereochemical revision of the fungal metabolite pestalospirane B. Org. Lett. 2017, 19, 3414-3417. [CrossRef] [PubMed]

Sample Availability: Samples of the compounds are available from the authors.

(C) 2019 by the authors. Licensee MDPI, Basel, Switzerland. This article is an open access article distributed under the terms and conditions of the Creative Commons Attribution (CC BY) license (http://creativecommons.org/licenses/by/4.0/). 